Journal of Business and Management Research

ISSN: 2382-5219 (Print); 2467-9267 (Online)

January 2016, Vol.1, No.1, pp. 39-52

DOI: http://dx.doi.org/10.3126/jbmr.v1i1.14550

\title{
Relationship between Remittance and Credit Disbursement of the Banking Sector: A Study from Bangladesh
}

\author{
Dewan Muktadir-Al-Mukit ${ }^{1 *} \&$ Nazrul Islam² \\ ${ }^{1}$ Faculty of Business Administration, Eastern University, Dhaka, Bangladesh \\ ${ }^{2}$ School of Business Administration, Uttara University, Dhaka, Bangladesh
}

\begin{abstract}
The paper investigates the relationships of remittance with credit disbursement of the banking sector in Bangladesh. The major portion of the remittance in Bangladesh is transferred through different banks as official channel. Besides, remittance recipient families transfer a portion of the remittance in the deposit accounts of different commercial banks. This two-way process helps to increase the liquidity position of the bank that enables them to increase the credit disbursement position of the banks. Moreover, the use of this loan by the business entrepreneurs indirectly helps economic development of Bangladesh. This study uses time series econometric techniques with monthly data spanning from 1976 to 2012 to explore the relationships between the remittances and the credit disbursements of the banks. The findings of the study clearly show that remittances assist to enhance the amount of credit disbursements of the banking sector in Bangladesh. The normalized co-integrating coefficients are found statistically significant and show a stable and positive relationship between the variables under this study. Finally, Granger causality analysis suggests the existence of bidirectional causality between remittances and credit disbursements.
\end{abstract}

Keywords: Remittances, credit disbursement, banking sector development, cointegration, causality

\section{Introduction}

Remittances sent by migrant workers have become an increasingly important source of foreign exchange revenue for the economy of Bangladesh, which, in turn, also have salutary effect on the balance of payments of the country. Remittances also serve as the locomotive for economic growth, having profound impact on savings, investment and consumption while making more credit accessible to the economy. Economic activity cannot function efficiently without the continuing flow of money and credit, for which banks act as the primary facilitators of the flow of credit (Omankhanlen, 2012). It is said that the economic progress of a country is a function of advancement and growth of the banking industry (Agu, 1988; Nwankwo, 1994). Since remittances provide an important source of fund for these commercial banks, its inflow may have potential to contribute significantly to the South Asian economies and, as a corollary, toward its banking sector development (Hinojosa-Ojeda, 2003; Terry \&

\footnotetext{
* Corresponding Author.

Email: mukit@easternuni.edu.bd
} 
Wilson, 2005; World Bank, 2006). Remittance flow and credit disbursement for Bangladesh during 1976-2012 is shown in Figure 1.

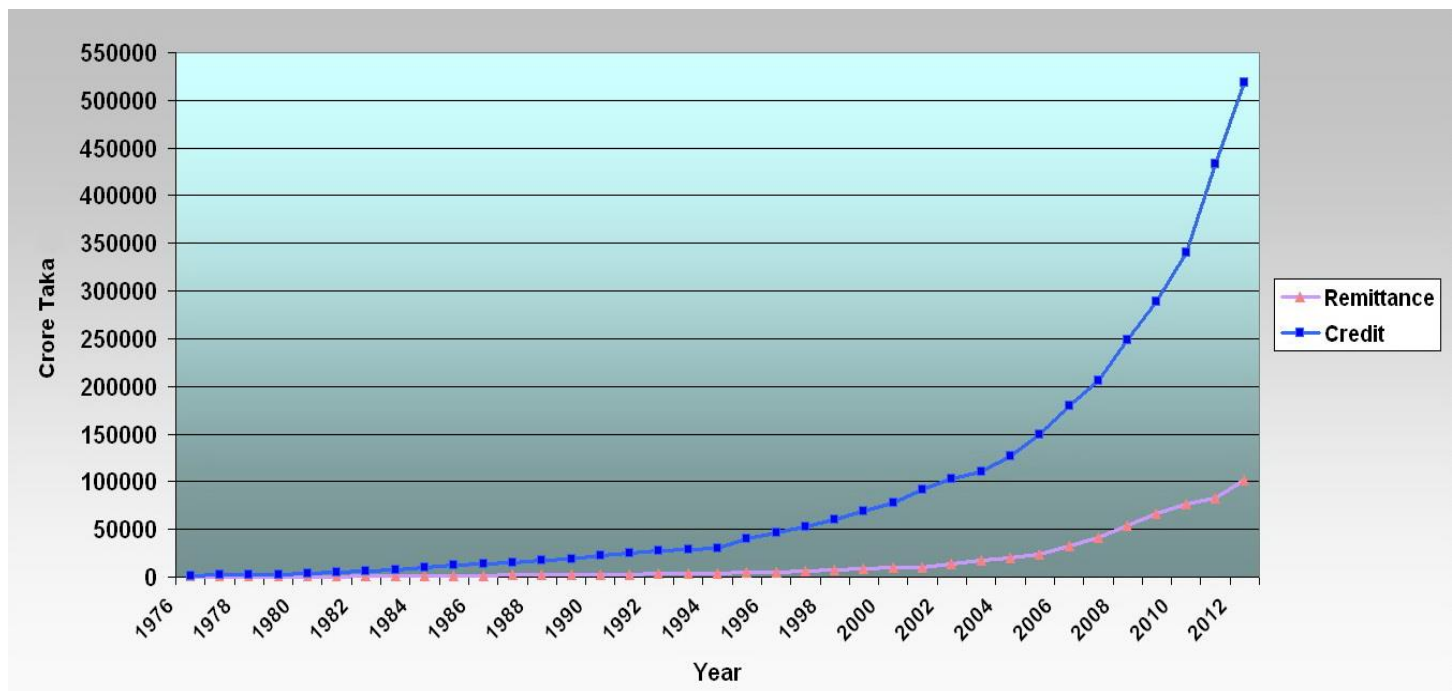

Figure 1. Remittance flow and credit disbursement over the sample period.

Figure 1 indicates that remittance income of Bangladesh has increased significantly in the last 36 years, which currently stands approximately at $10 \%$ of Gross Domestic Product (GDP). The figure also shows a close positive relationship between remittance flow and credit disbursement. For instance, in 1976, the remittance inflow of Bangladesh was Tk 0.25 million which had increased to Tk 10188.278 million in 2012. With regards to credit, credit disbursement by all banks in 1976 was Tk 175.66 million which increased to Tk 51833.54 million in 2012. Moreover, remittances have contributed to the economic growth through higher rates of capital accumulation in the banking system, which has also enhanced allocation of capital by reducing the credit constraints.

Remittances come to Bangladesh through both formal and informal channels. Fifty percent of the remittance flow recorded globally passes through the informal channel (World Bank, 2006). Regardless of this, remittances coming through formal or informal channels are positively associated with banking sector development (Aggarwal, Demirguc-Kunt, \& Peria, 2006). In this light, Motelle (2011) described such a positive relationship between remittances and financial development by arguing that demand for financial services could be increased during transferring or channelling of remittances into saving, and at the same time remittances can be viewed as the alternative source of financing for the entrepreneurs who are unqualified for credit from mainstream commercial banks. In fact, remittances help alleviate credit constraints on the investors, especially the poor who face credit constraint due to lack of collateral and thus remittances support entrepreneurial activities by improving the allocation of capital, and therefore accelerating economic growth (Giuliano \& RuizArranz, 2005). Moreover, Mundaca (2007) postulates that since efficient financial systems enjoy allocative efficiency, they can channel remittances towards the most productive investment projects. This screening is especially necessary when credit is extended to small and medium-sized enterprises. In this regard, Motelle (2011) has identified four ways to describe the substitutability hypothesis of the 
relationship between remittances and financial development. Motelle (2011) goes on explaining as follows:

First, as remittance recipients demand financial products such as bank accounts and debit or credit cards, the financial system becomes more consolidated. Second, if the remittances are in excess of immediate needs of the recipients, the surplus may be saved thereby boosting domestic resource mobilisation. Third, the regular flows of remittances into recipients' accounts make them eligible for bank credit, which in turn expands the size of the credit market. Fourth, remittance recipients can be eyed as a market segment and banks may want to take the largest share of this segment. This would encourage completion, reduce transfer costs, and result in more remittances. (pp. 243)

Though there are many research studies which focus primarily on the impact of remittances on economic growth, little attention has been given on the causality and association between remittances and credit segment. In addition, the issue is imperative as financial systems perform a number of key economic functions and their development has been found to foster growth and reduce poverty (Beck, Levine \& Loayza, 2000; Beck, Demirgüç-Kunt, \& Levine, 2005; King \& Levine, 1993) where intermediating remittances through the banking sector can multiply the developmental impact of remittance flows as well (Hinojosa-Ojeda, 2003; Terry \& Wilson, 2005; World Bank, 2006).

Bangladesh is a developing nation in Asia with around 154 million population where per capita income is $\$ 850$ with economy of $\$ 116.4$ billion GDP. As data suggest, each year thousands of Bangladeshis migrate to the Middle East and South Asia to work. According to the Bangladesh's Bureau of Manpower, Employment and Training (BMET), 425684 people left the country in 2014. As a gradual increase, the number of overseas employment of the country reached to total 9,171,139 till January, 2015. While the number of migrant workers of Bangladesh has increased over time, at the same time the number of commercial banks has also increased significantly. These increased workers' contribution to the foreign exchange revenue was facilitated by this financial sector in the process of dissemination of remittance through the banking channel. As the banking sector is the main source of channeling remittances, recipient families deposit some of their remittance earnings in banks. So, we expect that remittances have an immediate and direct effect on banks' ability for credit disbursement. This two-way process also helps the economic development of the country. In consonance with the above background, this research intends to examine the relationships between remittance and the credit disbursement amount by banking sector for the economy of Bangladesh. The following research question has been developed for the study purpose: Is there an association between remittances and credit disbursement in the banking sector of Bangladesh?

\section{Theoretical Background}

Remittance contributes significantly to the countries which are heavily import depended and thus remittance flows support these countries in order to minimize the problem arising from shortfall in foreign exchange reserve (Siddque \& Selvanathan, 2010). Therefore, remittance earning is considered an important source of foreign exchange earnings, especially in the developing countries. In order to channel these remittances, the role of financial intermediaries is vital. As a crucial part of financial intermediary, banks play an important role in efficient allocation of resources. As early as 1911, renowned economist Schumpeter (1934) recognized the role of banks in facilitating technological innovation through their intermediary role. They play this role through efficient allocation of savings in helping the entrepreneurs for implementing innovative products and production processes, which are 
the tools to achieve economic growth. Later, this proposition of significance of banks to the growth of the economy was supported by other scholars (Fry 1988; King \& Levine, 1993; McKinnon, 1973; Shaw 1973). A number of studies claim that the rapid economic growth and higher investment are associated with expansion and deepening of the financial system (Aghion, Angelatos, Banerjee, \& Manova, 2005; Beck et al., 2000; Demirgüç-Kunt \& Maksimovic, 1998; Levine, 2006; Rajan \& Zingales, 1998).

The apparent importance of remittances to the financial sector is highlighted by the efforts of financial intermediaries in encouraging the recipients to put their remittances in the financial system (Orozco \& Fedewa, 2006) which ultimately allows them to gain access to other financial products and services, from which they were denied access previously (Oke \& Okpala, 2011). If we consider monetary effects, there is an increase in the supply of money for the remittance recipient country, which in turn increases the availability of loanable funds and lowers the interest rates. Then with the increased liquidity banking sector is able to encourage borrowing. Since private investment is assumed to be inversely related to prevailing interest rates, investments expand as interest rates fall, and thereby contributing to higher levels of economic activity (Gani \& Sharma, 2013). The findings of Gupta, Pattillo, and Wagh (2007) based on the study of 44 Sub-Saharan African countries from 1975 to 2004 affirm that remittances promote financial development in these nations, after controlling for other macroeconomic and institutional variables influencing financial development and correcting for reverse causality between remittances, poverty and financial development. Likewise, Gani and Sharma (2013) attempted to determine the impact of remittances on the credit disbursement of the banking sector. They took sample of 57 low and middle-income countries from 1995 to 2008. Their empirical results provide evidence that remittance inflows in the low and upper middle-income countries are positively and significantly related to the domestic credit provided by the banking sector. Using county-level data for Mexico, Demirgüç-Kunt, Cordova, Peria, and Woodruff (2007) attempted to explore the impact of remittances on breadth and depth of the banking sector and reported a positive impact of remittances on credit.

If we study the findings of the researchers, it is obvious that remittances play an important role in the economic growth of a country. And this positive relationship between economic development and remittances is the result of a number of issues that include multiplier effects of consumption (Stahl \& Arnold, 1986), expansion of financial institutions (Aggarwal et al., 2006), increase of foreign exchange revenue (Ratha, 2005), and the use of remittances as alternative to microfinance (Guilamo \& Ruiz-Arranz, 2006). Mundaca (2009) also argued that remittances may potentially contribute to the country's long-run growth through higher rates of capital accumulation. The positive association between remittances and economic growth is revealed in the studies of a number of researchers (e.g. Aggarwal et al., 2006; Faini, 2001; Pradhan et al., 2008; Taylor, 1992). Taylor (1999) showed that every dollar Mexican migrants send or bring back home with them increases Mexico's GNP from anywhere between US\$2.69 and US\$ 3.17. This positive impact of remittances on economic development is the outcome of expansion of the financial system and financial sector development. Moreover, the impact of remittances on growth depends on the level of financial sector development of that country (Giuliano \& Ruiz-Arranz, 2005; Mundaca, 2007). Many researchers argue that private credit is a good predictor of economic growth (Beck et al., 2005; Crowley, 2008). The study of Bayoumi and Melander (2008) shows that a $2.5 \%$ reduction in the overall credit causes a reduction in the level of GDP by around $1.5 \%$. Similarly, Qubria (1986) showed that the flows of remittances can reduce the foreign exchange constraints with improvement of the balance of payments and contribute to augment the national savings. Aggarwal et al. (2006) conducted a study of 99 countries over the 
period 1975-2003 and found that remittances have a positive impact on bank deposits and subsequently increase in GDP. Using short-run Keynesian structural equation type model, Murshid et al. (2002) also attempted to determine the impact of remittance on economic growth of Bangladesh and the result showed a one million taka increase in remittances would increase national income by 3.33 million taka.

Most studies on remittances have focused on their impacts on economic growth and in many cases on health, education or entrepreneurship (Demirgüç-Kunt et al., 2007; Oke \& Okpala, 2011) but little attention has been paid to the question of whether remittances affect the financial sector in recipient countries, especially on the lending position of the financial intermediaries. The notion that remittances can lead to financial development is based on a number of concepts. Remittances can enhance growth not only by increasing investment in physical and human capital but also by developing efficient financial system in the recipient country (Chami et al., 2008). The impact of remittances in the economic development can be decomposed into their effects on consumption, savings, and investment. Remittance is a part of total disposable income of the households which is used to buy good and sometimes in investment in micro business. And the rest goes to savings. The study by Mahmud and Osmani (1980) revealed that in Bangladesh the highest remittances receiving income group's saving ratio was found to be almost three fourth of income. Surely, the major part of this savings goes to banking sector in the form of deposit. At the same time, in order to achieve economic development properly, a nation must ensure the productive use of remittances. And as a part of financial system, banks can play a vital role in ensuring productive use of that resources. Every bank is perceived to serve the need of the credit requirements and banks translate that credit function through different loans and investment functions to meet that obligation (Sebastian, 2009). The studies of Siddiqui and Abrar (2003) and Azad (2004) elaborated on the role of micro finance institutions (MFI) in Bangladesh for channeling inward remittances and directing them to productive usage. Siddidui (2004) classified the different types of agents and institutions involved in remittances' transfer process in Bangladesh including commercial banks. The study of Hassan et al. (2012) also suggested that positive effect of remittances on the growth rate of the economy is channeled through its interaction with the financial sector of Bangladesh. Orozco and Fedewa (2005) attempted to explain the way by which remittances can influence the financial sector. Their notion was that money transferred through financial institutions creates the way for remittance recipients to demand and gain access to other financial products and services. Indeed, remittances have been shown to alleviate the credit constraints faced by most people in developing countries (Funkhouser, 1992; Woodruff \& Zenteno, 2004). Furthermore, an increase in remittances may not necessarily increase credit to the private sector if banks prefer to hold liquid assets rather than lending or if they prefer to lend to the public sector instead of the private sector (Orozco \& Fedewa, 2005; Aggarwal et al., 2006).

From the above discussion, it is obvious that remittances have a significant impact on the economic development through proper utilization of resources, however, the impact of remittances on credit amount of the financial sector remains largely unexplored. This paper attempts to fill this gap in the literature by determining the functional relationship between remittances and credit disbursement.

\section{Methods}

The data set of this study comprises yearly time series from 1976 to 2012. The data on remittance inflow and credit disbursement were collected from "Bangladesh Bank Monthly Economic Trend" and 
"Bangladesh Bank Website". Here, remittances are current transfers by migrants who are employed in another country or economy and expressed in Crore Taka. On the other hand, credit is the total domestic credit disbursed by all public and private sector banks of the country and expressed in Crore Taka. All data are transformed into natural logarithms form where LREM is the natural logarithm of remittance and LCREDIT is the natural logarithm of credit.

To check for non-stationarity property, the data were subjected to Augmented Dickey and Fuller Test (ADF test). When working with non-stationary time series, there is a need to test the presence of unit roots in order to determine how many times a variable needs to be differenced to result in a stationary series. Using Schwarz Information Criterion (SIC), the lag length is selected automatically by E-views-7. If the data are stationary at first difference, then we proceed with co-integration test. Cointegration is a precondition for the existence of a long run equilibrium relationship between two or more variables having unit roots. In testing for co-integration, we have chosen the Johansen Maximum Likelihood method, for which optimal lag order is selected by employing Final Prediction Error (FPE), Akaike Information Criterion (AIC), Schwarz Information Criterion (SC) and Hannan-Quinn Information Criterion (HQ).

If there is at least one co-integrating relationship among the variables, one can proceed to carry out Vector Error Correction Model (VECM) that provides information about the speed of adjustment to long run equilibrium avoiding the spurious regression problem (Engle \& Granger, 1987). Diagnostic checks have been carried out to the estimated VECM model by employing Jarque-Bera (J-B) test for normality, Lagrange Multiplier (LM) test for serial correlation and White Test with cross products for heterosedasticity.

After VECM model was estimated, we employed Variance Decompositions to investigate the behavior of an error shock to remittances on its own future dynamics as well as on the future dynamics of the credit variable. The last step of our analysis was to test for causality between remittance and credit in the long run based on Granger Causality Test.

\section{Results}

We started our analysis by using Augmented Dickey and Fuller (ADF) test to identify non-stationarity property of the data. Our result of Johansen procedure of Co-integration test shows whether the variables have a stable and non-spurious co-integrating relationship. The short run causal relationship among the study variables has been identified by Vector Error Correction Model (VECM). Finally, the result of our Granger causality test shows the direction of causality between the study variables in the long run.

\section{The Unit Root Test}

Table 1 shows the results of ADF test statistics. After the first differencing, LREM and LCREDIT became stationary at the $1 \%$ significance level, implying that both variables are first order integrated I(1). Likewise, Figure 2 shows stationarity after the first differencing of the variables.

\section{Testing Co-integration}

As the variables are considered to be I(1), the Johansen's method requires selecting an appropriate lag length to use in estimation of the long run relationship between the variables. The results for various statistics of lag length selection are reported in Table 2. 
Table 1

Results of ADF Test

\begin{tabular}{lllll}
\hline & LREM & & \multicolumn{2}{l}{ LCREDIT } \\
\cline { 2 - 5 } & Level & First difference & Level & First difference \\
\hline Without Trend & $-3.91 * *$ & $-5.24 * *$ & -1.25 & $-4.14 * *$ \\
With Trend & -2.82 & $-5.09 * *$ & -2.16 & $-4.23 * *$ \\
\hline
\end{tabular}

Note: $* * p<.01$

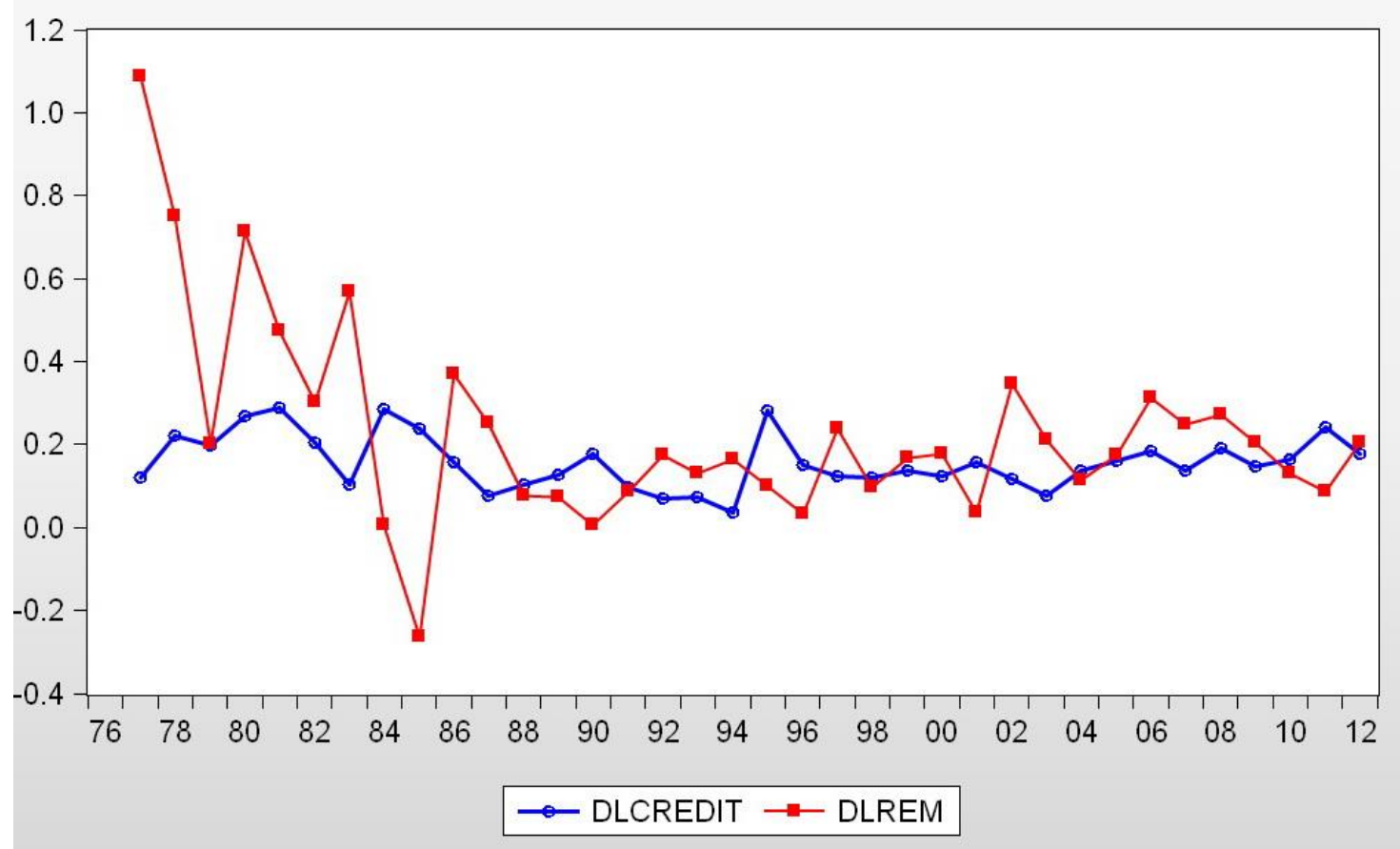

Figure 2. Trend with stationary

Table 2

Lag Length Selection

\begin{tabular}{ccccc}
\hline Lag & FPE & AIC & SC & HQ \\
\hline 0 & 0.09 & 3.30 & 3.39 & 3.33 \\
1 & 0.00 & -3.30 & $-3.09^{*}$ & -3.27 \\
2 & 0.00 & -3.36 & -2.91 & -3.21 \\
3 & 0.00 & $-3.71^{*}$ & -3.08 & $-3.49^{*}$ \\
\hline
\end{tabular}

Note: * lag order selected by the criterion calculated using Eviews-7 software 
As reported in Table 2, FPE, AIC and HQ suggest that the appropriate lag length for the model is ' 3 ' while SC suggests that the appropriate lag length is ' 1 '. Thus, the appropriate lag length that is selected in current analysis is ' 3 ' which satisfies most of the criteria.

The results of the two types of log-likelihood ratio tests, i.e. the trace statistics and the maximal eigenvalue, used to determine the numbers of co-integrating vectors are reported in Table 3.

Table 3

Unrestricted Co-integration Rank Test

(Trace)

\begin{tabular}{|c|c|c|c|c|}
\hline \multicolumn{2}{|l|}{ Hypothesized } & \multicolumn{3}{|c|}{.05} \\
\hline No. of CE(s) & Eigenvalue & Trace Statistic & Critical Value & $p$-value ${ }^{1}$ \\
\hline None & 0.47 & 22.46 & 15.49 & .00 \\
\hline At most 1 & 0.04 & 1.26 & 3.84 & .26 \\
\hline \multicolumn{5}{|c|}{ (Maximum Eigenvalue) } \\
\hline \multicolumn{2}{|l|}{ Hypothesized } & \multicolumn{3}{|c|}{.05} \\
\hline No. of CE(s) & Eigenvalue & Max-Eigen Statistic & Critical Value & $p$-value ${ }^{1}$ \\
\hline None & 0.47 & 21.20 & 14.26 & .00 \\
\hline At most 1 & 0.04 & 1.26 & 3.84 & .26 \\
\hline
\end{tabular}

1 MacKinnon-Haug-Michelis (1999) $p$-values

Both Trace and Maximal Eigen statistics identified one co-integrating vector. The presence of cointegration is the evidence of existence of a stable and long run relationship between remittance and credit. The results of co-integrating coefficients are reported in Table 4 . The significant coefficient sign implies that in the long run the relationship between remittance and credit is positive. It indicates that an increase in remittance flow by one percent is followed by 0.92 percent increase in credit disbursement. So, we can reject our null hypothesis and accept the alternate one which indicates that there is an association between remittances and credit disbursement.

Table 4

Co-integrating Equation

\begin{tabular}{lllll}
\hline Variables & Coefficient & Std. Error & $t$ - Statistic & $p$-value \\
\hline LREM & 0.92 & 0.02 & 47.90 & .00 \\
Constant (C) & 2.71 & 0.17 & 16.38 & .00 \\
$R^{2}$ & 0.93 & & & \\
Adj. $R^{2}$ & 0.93 & & & \\
\hline
\end{tabular}

Vector Error Correction Model

Vector Error Correction Model (VECM) was employed to determine the level of short run adjustment towards long run equilibrium relationship between the variables. We considered the following VECM with three lags:

Journal of Business and Management Research, January 2016, Vol. 1, No. 1 


$$
\Delta \mathrm{Y}_{\mathrm{t}}=\alpha \beta^{\prime} \mathrm{Y}_{\mathrm{t}-1}+\Gamma_{1} \Delta \mathrm{Y}_{\mathrm{t}-1}+\Gamma_{2} \Delta \mathrm{Y}_{\mathrm{t}-2}+\Gamma_{3} \Delta \mathrm{Y}_{\mathrm{t}-3}+\mathrm{u}_{\mathrm{t}}
$$

In this case, $Y_{t}=$ [LCREDIT LREM]', $\alpha$ is adjustment coefficient vector and is $2 \times 1, \beta^{\prime}$ is $1 \times 2$ cointegrating vector. $\beta^{\prime} \mathrm{Y}_{\mathrm{t}-1}$ is $\mathrm{I}(0)$ is required to yield the co-integrating regression and is also called error correction mechanism (ECM).

The results of VECM are shown in Table 5. The coefficient of the error correction term shows negative sign for $\Delta$ LCREDIT. The estimated error correction coefficient indicates that the credit is adjusting to long run equilibrium at a rate of about 12.35 percent each period in the short run. The negative sign of LCREDIT indicates a downward adjustment in the next period. On the other hand, the positive sign of LREM indicates an upward adjustment in the next period.

Table 5

Error Correction Model

\begin{tabular}{lrr}
\hline Regressors & $\Delta$ LCREDIT & $\Delta$ LREM \\
\hline ECM $_{\mathrm{t}-1}$ & $-0.12[-1.92]$ & $0.55[4.74]$ \\
$\Delta$ LCREDIT(-1) & $0.14[0.88]$ & $-0.34[-1.17]$ \\
$\Delta$ LCREDIT(-2) & $-0.14[-0.87]$ & $1.16[3.85]$ \\
$\Delta$ LCREDIT(-3) & $-0.27[-1.36]$ & $-0.02[-0.07]$ \\
$\Delta$ LREM(-1) & $0.08[1.21]$ & $0.31[2.58]$ \\
$\Delta$ LREM(-2) & $0.04[0.68]$ & $0.10[1.01]$ \\
$\Delta$ LREM(-3) & $0.04[0.68]$ & $0.10[1.01]$ \\
C & $0.15[4.06]$ & $-0.09[-1.41]$ \\
Adjusted $R^{2}$ & & 0.37 \\
\hline
\end{tabular}

Note: Figures in parenthesis represent the t-statistics

Table 6

Diagnostic Checks Analysis

\begin{tabular}{lcc}
\hline \multicolumn{2}{l}{ VEC Residual Serial Correlation LM Tests } & $p$-value \\
\hline Lags & LM-Stat & .18 \\
1lag & 6.22 & .67 \\
2lag & 2.33 & .80 \\
3lag & 1.67 & $p$-value \\
\multicolumn{2}{l}{ VEC Residual Normality Tests-Joint J-B test (Orthogonalization: Cholesky (Lutkepohl) } \\
\hline \multicolumn{3}{c}{ Joint test of Chi-square } \\
2.77 \\
VEC Residual Heteroskedasticity Tests \\
\hline \multicolumn{2}{c}{ Joint test of Chi-square } \\
49.84
\end{tabular}


To check the validity of our models, we also carried out diagnostic checks analysis employing LM test for serial correlation, J-B test for normality, and White test with cross products for heteroskedasticity and are reported in Table 6. The diagnostics tests indicate the considered model to be well specified.

To test for parameter stability, we took the Cumulative Sum of Square Method (CUSUMQ) into account. According to Figure 3, CUSUMQ tests for aggregate model do not show any structural breaks as the whole sum of recursive errors does not get outside the two critical lines at $5 \%$ significance level.

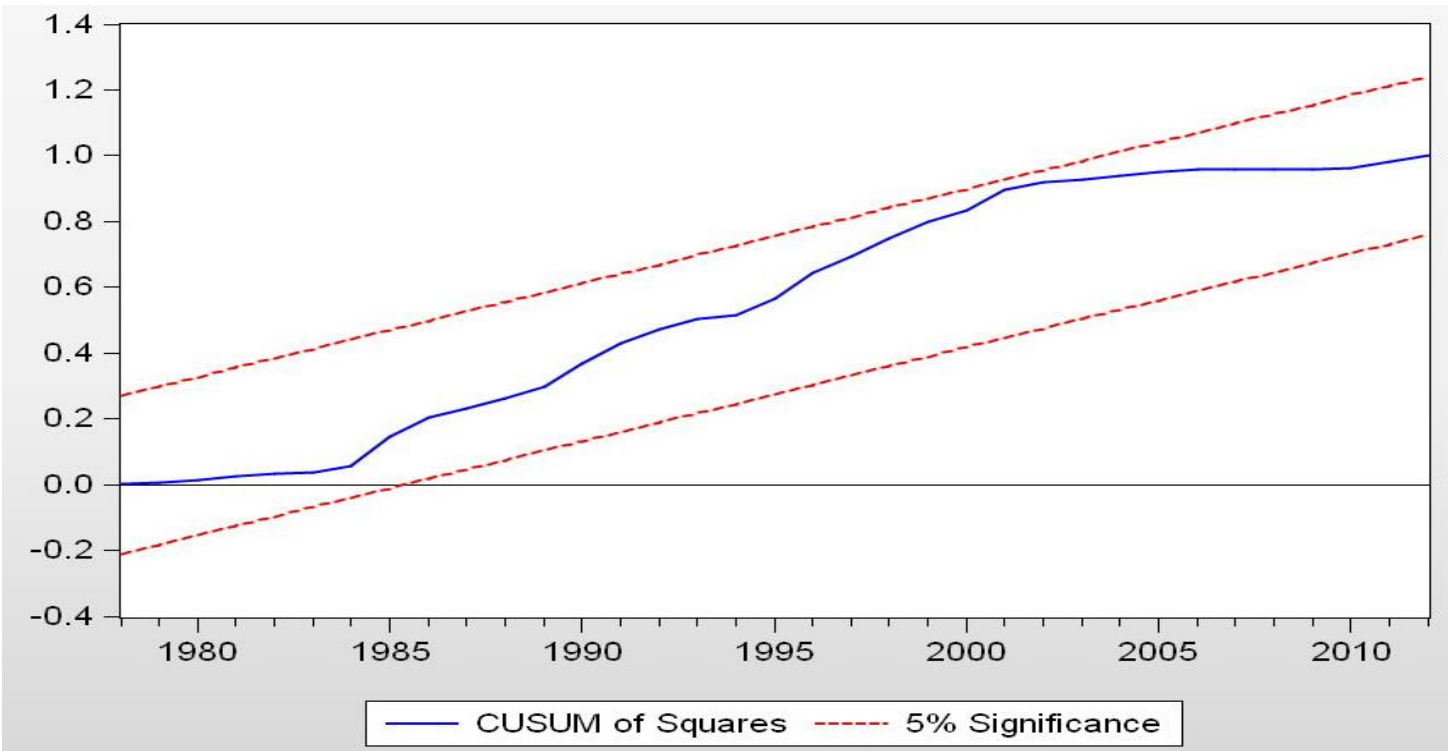

Figure 3. CUSUMQ test for aggregate model.

Table 7

The Results of Variance Decomposition

\begin{tabular}{ccc}
\hline Period & S.E. & LREM -> LCREDIT \\
\hline 1 & 0.13 & 0.00 \\
2 & 0.17 & 5.09 \\
3 & 0.24 & 14.10 \\
4 & 0.29 & 24.95 \\
5 & 0.34 & 29.10 \\
6 & 0.38 & 27.45 \\
7 & 0.42 & 26.60 \\
8 & 0.45 & 27.05 \\
9 & 0.48 & 27.03 \\
10 & 0.51 & 26.10 \\
11 & 0.53 & 24.79 \\
12 & 0.56 & 23.75 \\
\hline
\end{tabular}

Journal of Business and Management Research, January 2016, Vol. 1, No. 1 


\section{Variance Decomposition}

Variance decomposition and innovation impulse reaction have been performed for stationary data. We employed variance decomposition to measure the percentage of forecast error variance that is due to LREM on LCREDIT for periods up to 12; the results are presented in Table 7. During the second period, about $5 \%$ variation in credit is due to the variation in remittance and it fluctuates over the periods up to about $23.75 \%$ in the twelfth period indicating significant predicting power of LREM on LCREDIT.

\section{Granger Causality Test}

As there was a lagged relationship between the variables, Granger Causality test was applied to determine the direction of such relation. The results are presented in Table 8.

Table 8

Granger Causality Test

\begin{tabular}{llcc}
\hline Null Hypothesis & $F$-Statistic & $p$-value & $\begin{array}{l}\text { Granger } \\
\text { Causality }\end{array}$ \\
\hline LREM does not Granger cause LCREDIT & 2.65 & .09 & Yes \\
LCREDIT does not Granger cause LREM & 4.91 & .01 & Yes \\
\hline
\end{tabular}

Granger-causality results suggest that the null hypotheses that LREM does not Granger cause LCREDIT is rejected at 10\% significance level and LCREDIT does not Granger cause LREM is rejected at 5\% significance level; which states that there is a bi-directional causality between the variables.

\section{Discussion}

The study aims to determine the relationship between remittance and credit disbursements amount of the banking sector in Bangladesh. The data have been analyzed using time series econometric techniques, namely, VAR and VECM modeling. Johansen's co-integration test suggests one cointegrating relationship between the variables. The result shows that in the long run the association between remittance and credit disbursement is positive, with a positive impact of remittance on the credit amount. On the other hand, Granger causality analysis suggests that there exists a bi-directional causality between the variables. This can be interpreted as: increase of remittance causes increase in the liquidity position of the banks which enables them to enhance credit disbursement. So, the problem of lack of investment due to credit constraint was overcome and investment opportunities were improved in the economy. The causality from credit disbursement to remittance indicates an overreaching effect on the overall socioeconomic environment. One of the major progresses is educational development in addition to the growing industrialization. Moreover, both help to develop the manpower skills. The more the skills develop, the more opportunities are created for migrant workers. This results in more remittance inflow. 


\section{Implications and Future Research Direction}

At the policy level, the study suggests that the government should take necessary steps to ensure and promote channeling of remittances through the financial system of the country. At the same time, as majority of the migrant people of Bangladesh are laborers, we should emphasize to develop the manpower skills so that these migrant workers can be valued more which will help them to get more foreign earnings.

The limitations of this study can create an opportunity for further research work in this field. By increasing the time frame and incorporating other macroeconomic factors, future researchers can observe whether there is any difference in the results. Besides credit disbursement, researchers can consider other indicators for banking sector performance such as deposits, assets, and money supply. Finally, future studies can be conducted incorporating other developing countries in the study and the results can be compared with the other countries of the region as well as with the developed countries.

\section{References}

Aghion, P., Angelatos, G. M., Banerjee, A., \& Manova, K. (2005). Volatility and growth: Credit constraints and productivity-enhancing investment (NBER Working Paper No. 11349). Cambridge, England: National Bureau of Economic Research. http://dx.doi.org/10.1093/acprof:oso/9780199248612.001.0001

Aggarwal, R., Demirguc-Kunt, A., \& Peria, M. M. S. (2006). Do workers' remittances promote financial development? (World Bank Policy Research Working Paper No. 3957). Washington, DC: World Bank. http://dx.doi.org/10.1596/1813-9450-3957

Agu, C. C. (1988). Nigerian banking structure and performance: The banking system's contribution to economic development. Onitsha, Nigeria: African-Fep Publishers.

Azad, A. K. (2004). Migrant workers' remittance: Can it be a source of finance for micro-enterprise development in Bangladesh? Retrieved from http://pksf-bd.org/ pksfbd/images/download/Linking\%20International\%20Migrant.pdf

Bayoumi, T., \& Melander, O. (2008). Credit matters: Empirical evidence on US macro-financial linkages (IMF Working Paper No. 08169). Washington, DC: International Monetary Fund.

Beck, T., Demirguc-Kunt A., \& Levine R. (2005). Bank supervision and corruption in lending (NBER Working Paper No. 11498). Cambridge: National Bureau of Economic Research. http://dx.doi.org/10.3386/w11498

Beck, T., Levine, R., \& Loyaza, N. (2000). Financial intermediation and growth: Causality and causes. Journal of Monetary Economics, 46, 31-77. http://dx.doi.org/10.1016/S0304-3932(00)00017-9

Chami, R., Barajas, A., Cosimano, T. F., Fullenkamp, C., Gapen, M. T., \& Montiel, P. (2008). Macroeconomic consequences of remittances (IMF Occasional Paper No. 259). Washington, DC: International Monetary Fund.

Crowley J. (2008). Credit growth in the Middle East, North Africa and Central Asia region (IMF Working Paper No. 08/184). Washington, DC: International Monetary Fund.

Demirgüç-Kunt, A., \& Maksimovic, V. (1998). Law, finance, and firm growth. Journal of Finance, 53, 2107-2137. http://dx.doi.org/10.1111/0022-1082.00084

Demirgüç-Kunt, A., Cordova, E. L., Peria, M. S. M., \& Woodruff, C. (2007). Remittances and banking services: Evidence from Mexico. Washington, DC: World Bank, Development Research Group.

Faini, R. (2001). Development, trade, and migration. Washington, DC: International Monetary Fund. 
Fry, M. J. (1988). Money, interest and banking in economic development. London, England: John Hopkins University Press.

Funkhouser, E. (1992). Migration from Nicaragua: Some recent evidence. World-Development, 20(8), 1209-1218. http://dx.doi.org/10.1016/0305-750X(92)90011-J

Gani, A., \& Sharma, B. (2013). Remittances and credit provided by the banking sector in developing countries. International Review of Business Research Papers, 9(3), 85-98.

Giuliano, P., \& Ruiz-Arranz, M. (2005). Remittances, financial development, and growth (IMF Working Paper No. 05/234). Washington, DC: International Monetary Fund.

Gupta, S., Pattillo, C. A., \& Wagh, S. (2007). Impact of remittances on poverty and financial development in Sub-Saharan Africa (IMF Working Paper No. WP/07/38). Retrieved from http://www.imf.org/external/pubs/ft/wp/2007/wp0738.pdf

Hassan, G., Shakur, S., \& Bhuyan, M. (2012). Nonlinear growth effect of remittances in recipient countries: An econometric analysis of remittances-growth nexus in Bangladesh (MPRA Paper No. 40086). Munich, Germany: University Library of Munich. Retrieved from: http://mpra.ub.unimuenchen.de/40086/1/MPRA_paper_40086.pdf

Hinojosa-Ojeda, R. (2003). Transnational migration, remittances and development in North America: Globalization lessons from the Oaxaca-California transnational village/community modeling project. Mexico City, Mexico: World Bank.

King, R. G., \& Levine, R. (1993). Finance and growth: Schumpeter might be right. Quarterly Journal of Economics, 108, 717-738. http://dx.doi.org/10.2307/2118406

Levine, R. (2006). Finance and growth: Theory, evidence, and mechanisms. In P. Aghion \& S. Durlauf (Eds.), Handbook of economic growth (pp. 865-934). Amsterdam, the Netherlands: North-Holland Elsevier Publishers.

McKinnon, R. (1973). Money and capital in economic development. Washington, DC: The Brookings Institute.

Mahmud, W., \& Osmani, S. R. (1980). Impact of emigrant workers' remittances on the Bangladesh economy. Bangladesh Development Studies, 8(3), 1-28.

Mottele, S. I. (2011). The role of remittances in financial development in Lesotho: Evidence from alternative measures of financial development. Journal of Development and Agricultural Economics, 3(6), 241-251.

Mundaca, B. G. (2007). Can remittances enhance economic growth? The role of financial markets development. Retrieved from

http://www.ibrarian.net/navon/paper/Can_remittances_enhance_economic_growth_The_role.pdf? paperid $=16130268$

Mundaca, B. G. (2009). Remittances, financial market development, and economic growth: The Case of Latin America and the Caribbean. Review of Development Economics, 13(2), 288-303. http://dx.doi.org/10.1111/j.1467-9361.2008.00487.x

Murshid, K., Iqbal, K., \& Ahmed, M. (2002). A study on remittance inflows and utilization. Dhaka: International Organization for Migration.

Nwankwo, F. O. (1994). Rural savings mobilization. Indigenous Savings and Credit Association in IMO State, Nigeria. Germany: LIT Verlag Münster-Hamburg.

Oke, B. O., \& Okpala, O. P. (2011). Impact of workers' remittances on financial development in Nigeria, International Business Research, 4(4), 218-225. http://dx.doi.org/10.5539/ibr.v4n4p218

Omankhanlen, A. E. (2012). The role of banks in capital formation and economic growth: The case of Nigeria. Economy Transdisciplinarity Cognition, 15(1), 103-111. 
Orozco, M., \& Fedewa, R. (2006). Leveraging efforts on remittances and financial intermediation (Working Paper No. 24). Washington, DC: Inter-American Development Bank.

Orozco, M., \& Fedewa, R. (2005). Regional Integration? Trends and patterns of remittance flows within South East Asia. Washington, DC: Inter-American Dialogue.

Pradhan, G., Upadhyay, M., \& Upadhyaya, K. (2008). Remittances and economic growth in developing countries. The European Journal of Development Research, 20(3), 497-506. http://dx.doi.org/10.1080/09578810802246285

Quibria, M. G. (1986). Migrant workers and remittances: Issues for Asian developing countries. Asian Development Review, 4(1), 78-99.

Rajan, R., \& Zingales, L. (1998). Financial development and growth. American Economic Review, 88, 559-86.

Ratha, D. (2005). Remittances: A lifeline for development. Finance and Development, 42(4). Retrieved from: http://www.imf.org/external/pubs/ft/fandd/2005/12/basics.htm

Schumpeter, J. A. (1934). The theory of economic development (R. Opie, Trans.). Cambridge, MA: Harvard University Press.

Sebastian, O. U. (2009). Banking system credits to the domestic economy and national development. Economic and Administrative Series, 3, 149-164

Shaw, E. S. (1973). Financial deepening in economic development. New York, NY: Oxford University Press.

Siddiqui, T., \& Abrar, C. R. (2003). Migrant worker remittances and micro-finance in Bangladesh (Working Paper No. 38). Geneva: Social Finance Programme, International Labour Office.

Siddqui, T. (2004). Efficiency of migrant workers' remittances: The Bangladesh case. Manila: Asian Development Bank.

Siddque, A., Selvanathan, E. A., \& Selvanathan, S. (2010). Remittances and economic growth: Empirical evidence from Bangladesh, India and Sri Lanka. Retrieved from http://www.business.uwa.edu.au/_data/assets/pdf_file/0006/1371948/10-27-Remittances-andEconomic-Growth.pdf

Stahl, C., \& Arnold, F. (1986). Overseas workers' remittances in Asian development. International Migration Review, 20(4), 899-925. http://dx.doi.org/10.2307/2545742

Taylor, J. E. (1992). Remittances and inequality reconsidered: Direct, indirect and intertemporal effects. Journal of Policy Modeling, 14(2), 187-208. http://dx.doi.org/10.1016/0161$\underline{8938(92) 90008-Z}$

Taylor, J. E. (1999). The new economics of labour migration and the role of remittances in the migration process. International Migration, 37(1), 63-88. http://dx.doi.org/10.1111/14682435.00066

Terry, D. F., \& Wilson, S. R. (2005). Beyond small change: Making migrant remittances count. Washington, DC: Inter-American Development Bank.

Woodruff, C., \& Zenteno, R. (2004). Remittances and microenterprises in Mexico. Retrieved from http://dornsife.usc.edu/IEPR/Events/Papers/Christopher_Woodruff.pdf

World Bank. (2006). Global economic prospects: Economic implications of remittances and migration. Washington, DC: World Bank. http://dx.doi.org/10.1596/978-0-8213-6727-8 